\title{
Cryo-EM Studies of Virus-Antibody Immune Complexes
}

\author{
$\mathrm{Na} \mathrm{Li}^{1,2,3} \cdot$ Zhiqiang $\mathrm{Li}^{1,2,3} \cdot \mathrm{Yan}^{\mathrm{Fu}^{1,2}} \cdot$ Sheng $\mathrm{CaO}^{1,2}$ (D)
}

Received: 3 September 2019/ Accepted: 25 November 2019/Published online: 8 January 2020

(C) The Author(s) 2020

\begin{abstract}
Antibodies play critical roles in neutralizing viral infections and are increasingly used as therapeutic drugs and diagnostic tools. Structural studies on virus-antibody immune complexes are important for better understanding the molecular mechanisms of antibody-mediated neutralization and also provide valuable information for structure-based vaccine design. Cryo-electron microscopy (cryo-EM) has recently matured as a powerful structural technique for studying bio-macromolecular complexes. When combined with X-ray crystallography, cryo-EM provides a routine approach for structurally characterizing the immune complexes formed between icosahedral viruses and their antibodies. In this review, recent advances in the structural understanding of virus-antibody interactions are outlined for whole virions with icosahedral $\mathrm{T}=$ pseudo 3 (picornaviruses) and $\mathrm{T}=3$ (flaviviruses) architectures, focusing on the dynamic nature of viral shells in different functional states. Glycoprotein complexes from pleomorphic enveloped viruses are also discussed as immune complex antigens. Improving our understanding of viral epitope structures using virus-based platforms would provide a fundamental road map for future vaccine development.
\end{abstract}

Keywords Cryo-electron microscopy $($ Cryo-EM) $\cdot$ Icosahedral $\cdot$ Antigen $\cdot$ Virion $\cdot$ Immune complex

\section{Introduction}

Antibodies, the essential components of humoral immunity, are a major defense line against viral infections. To neutralize viral infections, antibodies primarily bind to specific epitopes on the outer surfaces of viral particles. An important first step in modern structural vaccinology involves structurally characterizing the interactions occurring between viral antigens and their cognate antibodies (Anasir and Poh 2019). This step provides the direct evidence for the location of viral epitopes, which helps to elucidate the neutralization mechanisms of antibodies. The first high-resolution structure of a virus (tomato bushy stunt virus) was solved four decades ago using X-ray

\section{Sheng Cao}

caosheng@wh.iov.cn

1 CAS Key Laboratory of Special Pathogens and Biosafety, Wuhan Institute of Virology, Wuhan 430071, China

2 Center for Biosafety Mega-Science, Chinese Academy of Sciences, Wuhan 430071, China

3 University of Chinese Academy of Sciences, Beijing 100049, China crystallography (Harrison et al. 1978), a technique that has been primarily limited to determining the structures of relatively simple non-enveloped viruses (http://viperdb. scripps.edu/xray.php) or viral components. Because crystallizing virus-antibody complexes can be challenging, morphological studies of virus-antibody interactions have long been carried out through transmission electron microscopy (TEM) with negative staining protocols (Almeida and Waterson 1969). The resolution achieved by this technique is usually low, but the structural details can be enhanced by modeling high-resolution crystal structures into low-resolution TEM maps. As the negatively-stained samples are visualizable with a conventional TEM instrument, they are still widely used today for characterizing immune complexes with human viruses like influenza A (Ekiert et al. 2012), Marburg (Flyak et al. 2015) and Ebola viruses (Flyak et al. 2016).

Cryo-electron microscopy (cryo-EM), a Nobelprize-winning technique, is now routinely used for studying virus-antibody complexes at high resolution (Earl and Subramaniam 2016). In contrast to negatively-stained samples, which might be significantly distorted by the dehydration process and the presence of stains, virus particles in cryo-EM studies are freshly frozen in a thin layer 
of vitreous ice to maintain their native conformations, making high-resolution analyses possible. However, before direct electron detection cameras (DEDs) were introduced in 2012, cryo-EM structures could only be solved at subnanometer resolutions with traditional CCD cameras, except some pioneer work based on images recorded on photographic film (Zhang et al. 2010). Largely resulting from the development of DED technologies, better microscopes and sophisticated reconstruction algorithms, cryo-EM has developed in recent years as a powerful highresolution technique in structural biology research (Shen 2018).

There are two major 3D cryo-EM analysis strategies: single particle analysis (SPA) and cryo-electron tomography (cryo-ET) (Danev et al. 2019). SPA is usually used for macromolecular assemblies that are stable, soluble and homogeneous in vitro. Because some viruses are highly structurally ordered, especially those with icosahedral symmetries, it is possible to solve the structures of whole viral particles at better than $3 \AA$ resolution using SPA by combining data from several thousands of purified virus particles (Jiang and Tang 2017). The density maps at this resolution allow the de novo building of atomic models. For viruses with pleomorphic shapes, 3D reconstruction of a single vitrified virion is achievable using cryo-ET procedures at $\sim 25-\AA$ resolution. Sub-tomogram averaging techniques are further exploitable for achieving better structural details for repeating structures, such as the surface glycoproteins on viruses. Both SPA and cryo-ET approaches have been used for structural studies on the interactions occurring between whole virions (or viral components) and their associated antibodies.

\section{Antibodies for Cryo-EM Studies}

Antibody molecules for cryo-EM studies can be generated in different ways. Mass production of murine monoclonal antibodies (mAbs) has traditionally been achieved by the use of hybridoma technology where antibody-producing B cells derived from immunized mice are fused to an immortalized cell line (e.g., myeloma) (Kohler and Milstein 1975). Recombinant antibodies can be generated by phage display technology followed by in vitro selection, which targets the whole virus particles or some viral components (Hoogenboom 2005). Various methods for isolating antigen-specific human B cells to obtain mAbs have also been reported (Crowe 2017). For viruses with naturally occurring high mutation rates like HIV-1, broadly neutralizing antibodies (bNAbs) that potently target a wide range of viral strains have been isolated from virus-infected individuals and extensively studied using cryo-EM (Stephenson and Barouch 2016; Chuang et al. 2019).
For cryo-EM analyses, the antibody components are IgG molecules or their truncated parts. In a single IgG molecule, two antigen binding fragments (Fabs) are present (Fig. 1A, 1B), a situation that could result in highly heterogeneous antigen-antibody complexes if one antigen particle becomes crosslinked with another. Except for SPA studies on IgG bivalency (Ye et al. 2016), IgG is usually used in cryo-ET studies at medium resolution for HIV-1 (Tran et al. 2012), influenza (Tran et al. 2016b) and Ebola viruses (Tran et al. 2016a). Compared with the intact IgG molecule, the monovalent $\mathrm{Fab}$ fragments generated by papain digestion of whole IgG molecules are more commonly used for structural studies on virus-antibody complexes (Tables 1, 2, 3). The single-chain variable fragment $(\mathrm{scFv})$ generated by fusing the variable regions of the heavy $\left(\mathrm{V}_{\mathrm{H}}\right)$ to the light $\left(\mathrm{V}_{\mathrm{L}}\right)$ chains with a flexible peptide linker (Finlay et al. 2017) can be used for cryo-EM studies of virus-antibody interactions (Kaufmann et al. 2009; Liu et al. 2017). Single-domain antibodies (sdAbs), such as variable domains of heavy chain-only antibodies (termed $\mathrm{VHH}$ ) and $\mathrm{V}_{\mathrm{H}}$ domains of human $\mathrm{IgG}$ molecules, have also served as antibody derivatives for cryoET studies when combined with sub-tomogram averaging (Meyerson et al. 2013).

Thus far, 3D reconstructions of virus-Fab complexes at atomic resolution are available for some picornaviruses, including rhinovirus B14 (RV-B14) (Dong et al. 2017), human parechovirus 3 (HPeV3) (Domanska et al. 2019), hepatovirus A (HAV) (Cao et al. 2019) and enterovirus D68 (EV-D68) (Zheng et al. 2019) (Table 1). The atomic models of the capsid protein were well-fitted in the cryoEM density map for HPeV3 (Fig. 1C, 1D). Nevertheless, only the $\mathrm{V}_{\mathrm{H}}$ and $\mathrm{V}_{\mathrm{L}}$ domains have clearly defined densities (Figs. 1E, 2G), whereas the density regions in the $\mathrm{C}_{\mathrm{H} 1}$ and $\mathrm{C}_{\mathrm{L}}$ domains are less ordered, reflecting the flexibility of the linker regions between the constant domains $\left(\mathrm{C}_{\mathrm{H} 1}\right.$ and $\left.\mathrm{C}_{\mathrm{L}}\right)$ and variable domains $\left(\mathrm{V}_{\mathrm{H}}\right.$ and $\left.\mathrm{V}_{\mathrm{L}}\right)$. Because the antigen binding site is determined by six hypervariable loops, namely, the complementarity-determining regions (CDRs) on the $\mathrm{V}_{\mathrm{H}}$ and $\mathrm{V}_{\mathrm{L}}$ domains, these densities can provide detailed information about the virus-antibody interface. Based on high-resolution structural analysis, CDRs from five HAV antibodies (R10, F4, F6, F7 and F9) interact with a single conserved antigenic site, which has been shown as an attractive target for rational development of antiviral drugs (Wang X et al. 2017; Cao et al. 2019).

\section{Icosahedral Viruses as Antigens in Cryo-EM Studies}

Viruses with icosahedral capsid shells are the most studied antigens in immune complexes by cryo-EM techniques, largely due to their high symmetry. Since perfect symmetry 
A
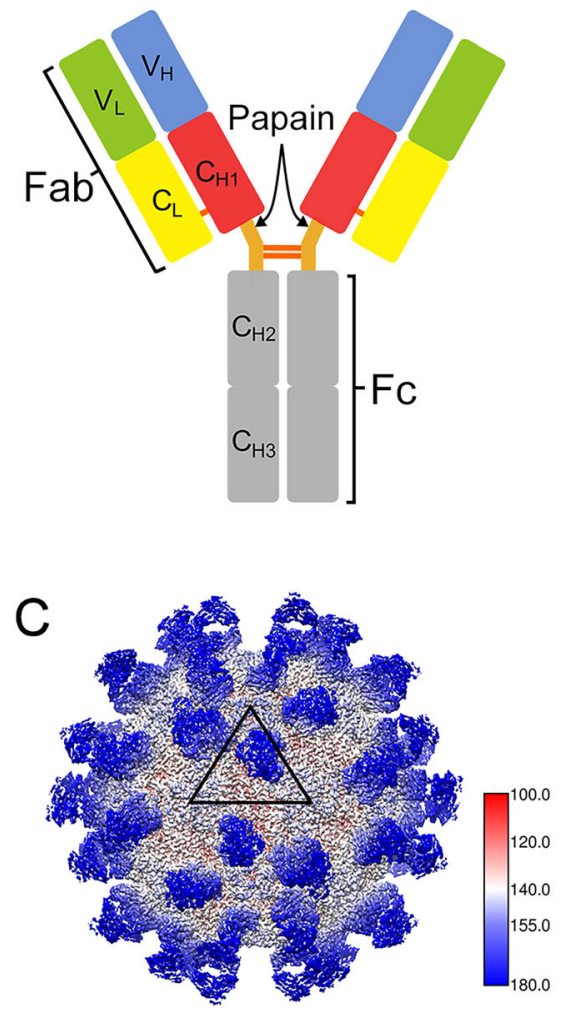

B

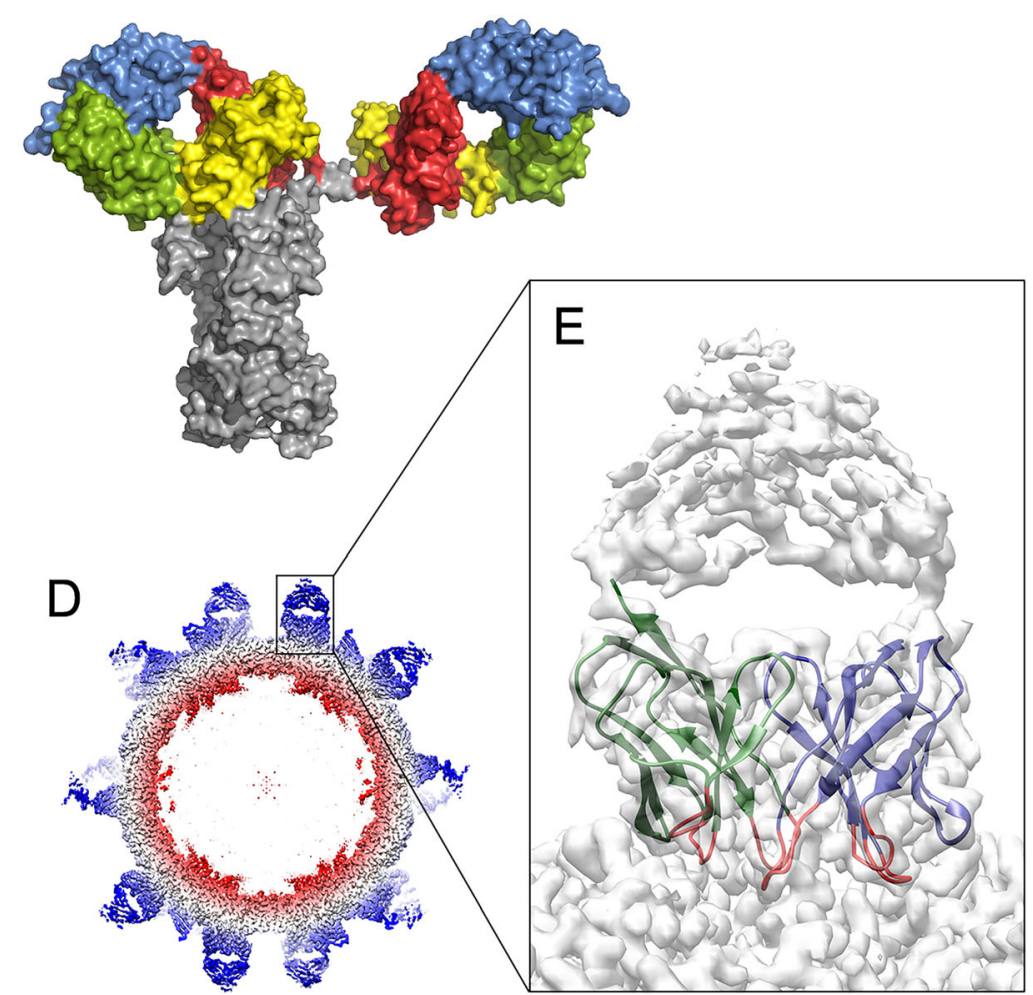

Fig. 1 Structural models of antibody molecules on the viral surface. A Modular organization of a Y-shaped IgG molecule, which consists of two heavy chains and two light chains covalently linked via disulfide bonds. Papain digestion of a parental antibody produces two Fab fragments and one $\mathrm{Fc}$ fragment. A Fab fragment comprises $\mathrm{V}_{\mathrm{H}}$, $\mathrm{C}_{\mathrm{H} 1}, \mathrm{~V}_{\mathrm{L}}$ and $\mathrm{C}_{\mathrm{L}}$ domains. B Surface illustration of highly asymmetric human IgG1 b12 (PDB-1HZH) colored by domain as in (A). C CryoEM map of Fab AT12-015 complexed with HPeV3 (EMD-0069), showing that the 60 copies of Fab (blue) are placed on the viral

could be broken as observed in many situations, such as symmetry mismatches at the portal vertex of herpesviruses (Parent et al. 2018) and partially mature particles of dengue viruses (Rodenhuis-Zybert et al. 2011), block-based or localized reconstruction strategies are now often applied to icosahedral particles showing conformational flexibility or symmetry mismatches (Ilca et al. 2015; Zhu D et al. 2018). Geometrically, an icosahedral object has 60 equivalent positions related by fivefold, threefold and twofold rotational symmetry. The 60 repeating units occupying each of these positions are referred to as asymmetric units (ASUs). The triangulation number (or T-number) is usually assigned to an icosahedral virus to identify the number of subunits in an ASU. In the simplest $\mathrm{T}=1$ virus (e.g., parvoviruses), only one capsid molecule is present in the ASU, and the 60 capsid protein copies form an enclosed shell to protect the viral genome. In contrast, in a $\mathrm{T}=3$ virus (e.g., flaviviruses), the ASU consists of three chemically identical capsid proteins (e.g., the E protein from surface (white). A triangular icosahedral asymmetric unit (ASU) is outlined on the capsid surface. The numbers show the positions of neighboring fivefold and two threefold axes limiting the ASU. D Central cross-section of the cryo-EM map showing the Fab densities (blue). $\mathbf{E}$ The enlarged inset shows the density corresponding to one Fab AT12-015 molecule. The $\mathrm{V}_{\mathrm{H}}$ and $\mathrm{V}_{\mathrm{L}}$ domains represented by green and blue ribbons are well defined in the density map. The six complementarity-determining regions in $\mathrm{V}_{\mathrm{H}}$ and $\mathrm{V}_{\mathrm{L}}$ are colored red.

flaviviruses), each of which undergoes conformational adjustments to occupy three "quasi-equivalent" positions in the ASU. Some icosahedral viruses show "pseudo" T geometry. Picornaviruses ( $\mathrm{T}=$ pseudo 3 ) have an ASU of three capsid protein types (VP1, VP2 and VP3), possibly making them a special $\mathrm{T}=1$ case. Next, we will examine the epitope distribution on these two types of humaninfection viruses, and also discuss the binding capacity of Fab molecules on their virions.

Small non-enveloped viruses in the Picornaviridae family cause mild or severe human infections, and provide important antigenic particles for cryo-EM studies (Table 1). Crystal structures of rhinovirus (Rossmann et al. 1985) and poliovirus (Hogle et al. 1985) have revealed that on the icosahedral capsid shell, VP1 lies close to fivefold axes and the neighboring VP2 and VP3 are found around threefold axes (Fig. 2A, 2B). Since 1997, outbreaks of hand-foot-and-mouth disease have been increasingly reported, the leading pathogens of which are various 
Table 1 Summary of cryo-EM structures from picornavirus-antibody complexes in the Electron Microscopy Data Bank (EMDB) (https://www. ebi.ac.uk/pdbe/emdb/).

\begin{tabular}{|c|c|c|c|c|c|c|}
\hline Genus & Virus name & Antigen & Antibody $^{\mathrm{a}}$ & Fragment & EMD codes & $\begin{array}{l}\text { Resolution } \\
(\AA)\end{array}$ \\
\hline \multirow[t]{36}{*}{ Enterovirus } & \multirow[t]{4}{*}{ Coxsackievirus (CV) } & CV-A6 A-particle & 1D5 & $\mathrm{Fab}$ & 6757 & 3.8 \\
\hline & & CV-A10 A-particle & $2 \mathrm{G} 8$ & $\mathrm{Fab}$ & 9603 & 4.3 \\
\hline & & CV-A10 mature virion & $2 \mathrm{G} 8$ & $\mathrm{Fab}$ & 9604 & 3.9 \\
\hline & & CV-A10 procapsid & $2 \mathrm{G} 8$ & $\mathrm{Fab}$ & 9605 & 4.2 \\
\hline & \multirow[t]{14}{*}{ Enterovirus (EV) } & \multirow[t]{5}{*}{ EV-A71 mature virion } & MA28-7 & $\mathrm{Fab}$ & 5673 & 23.4 \\
\hline & & & E18 & $\mathrm{Fab}$ & 2397 & 10 \\
\hline & & & E19 & $\mathrm{Fab}$ & 2436 & 13 \\
\hline & & & D5 & $\operatorname{IgG}$ & 6365 & 7.2 \\
\hline & & & D5 & $\mathrm{Fab}$ & 6366 & 4.8 \\
\hline & & \multirow[t]{5}{*}{ EV-A71 procapsid } & D5 & $\mathrm{Fab}$ & 6383 & 6 \\
\hline & & & 22A12 & $\mathrm{Fab}$ & 6200 & 8.8 \\
\hline & & & E18 & $\mathrm{Fab}$ & 2434 & 16 \\
\hline & & & D6 & $\mathrm{Fab}$ & 6963 & 4.9 \\
\hline & & & A9 & $\mathrm{Fab}$ & 6964 & 6.8 \\
\hline & & EV-A71 VLP & D5 & $\operatorname{IgG}$ & 6384 & 5.5 \\
\hline & & \multirow[t]{2}{*}{ EV-D68 mature virion } & $15 \mathrm{C} 5$ & $\mathrm{Fab}$ & 9633 & 3.6 \\
\hline & & & $\begin{array}{r}15 \mathrm{C} 5 / \\
11 \mathrm{G} 1\end{array}$ & $\mathrm{Fab}$ & 9634 & 3.5 \\
\hline & & EV-D68 A-particle & $11 \mathrm{G} 1$ & $\mathrm{Fab}$ & 9636 & 7.2 \\
\hline & \multirow[t]{16}{*}{ Poliovirus (PV) } & \multirow[t]{7}{*}{ PV1 mature virion } & A12 & $\mathrm{Fab}$ & 5670 & 12 \\
\hline & & & $\mathrm{C} 3$ & $\mathrm{Fab}$ & 5291 & 11.1 \\
\hline & & & PVSP6A & VHH & 5886 & 4.8 \\
\hline & & & PVSP29F & VHH & 5888 & 6.5 \\
\hline & & & PVSS8A & VHH & 6433 & 4.2 \\
\hline & & & PVSP19B & VHH & 6434 & 4.8 \\
\hline & & & PVSS21E & VHH & 6435 & 3.8 \\
\hline & & PV2 mature virion & A12 & $\mathrm{Fab}$ & 5671 & 20 \\
\hline & & \multirow[t]{2}{*}{ PV1 procapsid } & $\mathrm{P} 1$ & $\mathrm{Fab}$ & $\begin{array}{l}5283 / 5284 / 5285 / \\
5286\end{array}$ & $13 / 21 / 18 / 18$ \\
\hline & & & C3 & $\mathrm{Fab}$ & 5293 & 22 \\
\hline & & \multirow[t]{6}{*}{ PV1 A-particle } & $\mathrm{P} 1$ & $\mathrm{Fab}$ & $5280 / 5282$ & $12 / 26$ \\
\hline & & & $\mathrm{C} 3$ & $\mathrm{Fab}$ & 5292 & 9.1 \\
\hline & & & PVSP17B & VHH & 8285 & 5.3 \\
\hline & & & PVSS12B & VHH & 8285 & 5.3 \\
\hline & & & PVSS10E & VHH & 8277 & 4.8 \\
\hline & & & PVSS7A & VHH & 8286 & 5.3 \\
\hline & \multirow[t]{2}{*}{ Rhinovirus (RV) } & RV B14 mature virion & $\mathrm{C} 5$ & $\mathrm{Fab}$ & 8754/8761/8762 & $\begin{array}{l}2.53 / 2.71 / \\
2.26\end{array}$ \\
\hline & & RV B14 procapsid & $\mathrm{C} 5$ & $\mathrm{Fab}$ & 8763 & 3.01 \\
\hline Aphthovirus & $\begin{array}{l}\text { Foot-and-mouth disease virus } \\
\text { (FMDV) }\end{array}$ & $\begin{array}{l}\text { FMDV-O mature } \\
\text { virion }\end{array}$ & D9 & $\mathrm{Fab}$ & 0173 & 3.97 \\
\hline \multirow[t]{2}{*}{ Parechovirus } & \multirow[t]{2}{*}{ Human parechovirus (HPeV) } & HPeV-3 mature virion & AT12-015 & $\mathrm{Fab}$ & $0069 / 3138$ & $2.8 / 15$ \\
\hline & & HPeV-1 mature virion & AM28 & $\mathrm{Fab}$ & 2761 & 19.76 \\
\hline
\end{tabular}


Table 1 (continued)

\begin{tabular}{lllllll}
\hline Genus & Virus name & Antigen & Antibody & Fragment & $\begin{array}{l}\text { EMD codes } \\
(\mathrm{A})\end{array}$ \\
\hline Hepatovirus & Hepatovirus A (HAV) & HAV mature virion & R10 & Fab & 6688 & 4.2 \\
& & & F4 & Fab & 9827 & 3.9 \\
& & & F6 & Fab & 9828 & 3.68 \\
& & F7 & Fab & 9829 & 3.05 \\
& & F9 & Fab & 9830 & 3.79 \\
\hline
\end{tabular}

${ }^{a}$ Structural insights into the possible mechanisms for antibody-mediated neutralization discussed in the text are summarized below. 1D5: inhibition of virus-cellular binding (Xu et al. 2017), 2G8: capsid stabilization (Zhu R et al. 2018), MA28-7: cross-linking of virions and blocking receptor binding (Lee et al. 2013), E18: induction of genome release (Plevka et al. 2014), D5: capsid stabilization (Ye et al. 2016), 22A12: capsid stabilization (Shingler et al. 2015), D6: blocking receptor binding (Zhu L et al. 2018b), A9: blocking receptor binding and capsid destabilization (Zhu L et al. 2018b), 15C5: blocking receptor binding and locking capsid at intermediate stage, 11G1: locking capsid at intermediate stage (Zheng et al. 2019), R10: blocking receptor binding (Wang X et al. 2017), F4, F6, F7 and F9: blocking receptor binding (Cao et al. 2019).

enteroviruses, including enterovirus A71 (EV-A71), coxsackievirus A6 (CV-A6), CV-A10 and CV-A16 (Kimmis et al. 2018; Yu and Cowling 2019). Crystallographic and cryo-EM studies have shed some light on the uncoating mechanism of EV-A71, CV-A10 and CV-A16 (Wang et al. 2012; Ren et al. 2013; Zhu L et al. 2018a). Based on the cryo-EM structures of the enterovirus-Fab complexes, four neutralizing sites have been identified (Fig. 2E-2H) (Zhu R et al. 2018). Site 1 is located near the icosahedral fivefold axis of EV-A71 (MA28-7) (Lee et al. 2013), CV-A6 (1D5) (Xu et al. 2017) and EV-D68 (11G1) (Zheng et al. 2019). While site 2 maps to the VP1 GH-loop across the twofold axis of EV-A71 (22A12 and D5) (Shingler et al. 2015; Ye et al. 2016), site 3 is situated near the threefold axis of EV-A71 (E18, E19 and A9) (Plevka et al. 2014; Zhu L et al. 2018b) and EV-D68 (15C5) (Zheng et al. 2019). Site 4 is adjacent to the quasi threefold axis of CV-A10 (2G8) (Zhu R et al. 2018).

Some clinically relevant viruses in the Flaviviridae family, such as dengue virus (DENV), West Nile virus (WNV), Japanese encephalitis virus (JEV), tick-borne encephalitis virus (TBEV) and Zika virus (ZIKV) (Holbrook 2017; Yang et al. 2019), have been structurally studied as antigenic particles using cryo-EM (Table 2). In contrast with non-enveloped enteroviruses, flaviviruses possess host-derived lipid bilayers with 180 pairs of envelope (E) and membrane (M) proteins on the viral membrane (Perera and Kuhn 2008). Organized as head-totail homodimers on the outer surface (Fig. 2C, 2D), the E protein plays important roles in receptor binding and in mediating virus-host membrane fusion. Compared with picornaviruses, flavivirus epitopes do not possess an apparent pattern near symmetrical axes (Fig. 2I, 2J). Based on how Fab interacts with the E dimer, different epitopes on the DENV E protein are classifiable into four groups: (1) those that occur within an E monomer (e.g., 1F4) (Fibriansah et al. 2014); (2) those spanning the adjacent surface of two $\mathrm{E}$ molecules from neighboring $\mathrm{E}$ dimers (e.g., 14c10) (Teoh et al. 2012); (3) those consisting of amino acid residues from the two E molecules within an $\mathrm{E}$ dimer (e.g., 747(4)B7) (Dejnirattisai et al. 2015); and (4) those that occur across three neighboring E molecules (e.g., 5J7) (Fibriansah et al. 2015b). Largely based on antibody-E complex crystal structures, antibodies may target DI domain, DII fusion loop epitope (FLE) or DIII domain within an E monomer (Dai et al. 2016).

The distance between neighboring epitopes can impact the number of bound antibody molecules on each virion. Although both MA28-7 and 1D5 Fabs bind to site 1 of picornaviruses, only one MA28-7 Fab fragment occupies each fivefold vertex (Lee et al. 2013) while five 1D5 Fab molecules bind each fivefold vertex of CV-A6 (Xu et al. 2017). Compared with 1D5, Fab MA28-7 is closer to the symmetry axis, which renders steric hindrance between possible Fabs, thereby limiting the number of bound Fabs. As another example, the bivalent binding pattern of D5 was characterized in which the two Fab IgG fragments could bind to the GH loops of neighboring VP1 molecules related by twofold symmetry, a finding consistent with the observation that D5 IgG was able to neutralize EVA71 much more potently than D5 Fab (Ye et al. 2016). Contrastingly, the 22A12 binding sites near twofold axes on EVA71 are further apart and bivalent binding of an antibody cannot occur (Shingler et al. 2015). In some cases, Fab binding can even change the local arrangement of the E protein to accommodate more Fab molecules. For example, when the total 180 copies of Fab ZKA190 bind to the ZIKV surface, E proteins at the fivefold vertices move apart and steric clash is avoided (Wang J et al. 2017).

Structural variations in the capsid protein at quasiequivalent positions may also impact the number of bound Fab molecules. Within an ASU, the DENV E protein exists as three conformations showing slight structural variation. 180 copies of Fab 747(4)B7 in total can bind to a DENV virion (Dejnirattisai et al. 2015), suggesting that such variations have no apparent impact on the epitope. However, in other cases, conformational changes can result in a less effective epitope. For example, Fab 1F4 (targeting the 
Table 2 Summary of cryo-EM structures from flavivirus-antibody complexes.

\begin{tabular}{|c|c|c|c|c|c|}
\hline Virus name & Antigen & Antibody $^{\mathrm{a}}$ & Fragment & EMD codes & Resolution $(\AA)$ \\
\hline \multirow[t]{9}{*}{ Dengue virus (DENV) } & \multirow[t]{2}{*}{ DENV1 mature virion } & $14 \mathrm{c} 10$ & Fab & 5268 & 7 \\
\hline & & $1 \mathrm{~F} 4$ & Fab & 2442 & 6 \\
\hline & \multirow[t]{3}{*}{ DENV2 mature virion } & 747(4)B7 & Fab & 2818 & 10.24 \\
\hline & & 1A1D-2 & $\mathrm{Fab}$ & 1418 & 24 \\
\hline & & $2 \mathrm{D} 22$ & $\mathrm{Fab}$ & $\begin{array}{l}2967 / 2968 / 2969 / 2996 / 2997 / 2998 / \\
2999\end{array}$ & $\begin{array}{l}6.5 / 20 / 21 / 6.9 / 13 / 11 / \\
23\end{array}$ \\
\hline & \multirow{2}{*}{$\begin{array}{l}\text { DENV2 immature } \\
\text { virion }\end{array}$} & $2 \mathrm{H} 2$ & $\mathrm{Fab}$ & $5674 / 5675 / 5676 / 5677$ & $21 / 25 / 21 / 21$ \\
\hline & & E53 & Fab & 5102 & 23 \\
\hline & $\begin{array}{l}\text { DENV3 immature } \\
\text { virion }\end{array}$ & $1 \mathrm{H} 10$ & Fab & $9649 / 9650 / 9651$ & $12 / 25 / 25$ \\
\hline & DENV3 mature virion & $5 \mathrm{~J} 7$ & $\mathrm{Fab}$ & 5935 & 9 \\
\hline \multirow[t]{4}{*}{ West Nile Virus (WNV) } & Immature virion & E53 & $\mathrm{Fab}$ & 5103 & 15 \\
\hline & \multirow[t]{3}{*}{ Mature virion } & E16 & $\mathrm{Fab}$ & 1234 & 14.5 \\
\hline & & E16 & $\mathrm{scFv}$ & 5115 & 22.75 \\
\hline & & CR4354 & Fab & 5190 & 13.7 \\
\hline $\begin{array}{l}\text { Tick-borne encephalitis virus } \\
\text { (TBEV) }\end{array}$ & Mature virion & $19 / 1786$ & $\mathrm{Fab}$ & $3754 / 3755$ & $3.9 / 19.2$ \\
\hline \multirow[t]{7}{*}{ Zika virus (ZIKV) } & \multirow[t]{7}{*}{ Mature virion } & $\begin{array}{l}\text { ZIKV- } \\
117\end{array}$ & $\mathrm{Fab}$ & 8548 & 6.2 \\
\hline & & ZKA190 & Fab & $6793 / 6794$ & $22 / 22$ \\
\hline & & $\mathrm{Z} 23$ & $\mathrm{Fab}$ & 9542 & 9.4 \\
\hline & & $\mathrm{C} 10$ & $\mathrm{Fab}$ & $9573 / 9574 / 9575$ & $4.4 / 12 / 4$ \\
\hline & & $\begin{array}{l}\text { ZAb- } \\
\text { FLEP }\end{array}$ & $\mathrm{Fab}$ & 7613 & 9.7 \\
\hline & & ZK2B10 & Fab & $9811 / 9812$ & $20 / 11$ \\
\hline & & $\begin{array}{l}\text { ZIKV- } \\
195\end{array}$ & Fab & 9131 & 4 \\
\hline \multirow[t]{2}{*}{ Japanese encephalitis virus (JEV) } & \multirow[t]{2}{*}{ Mature virion } & $2 \mathrm{~F} 2$ & Fab & 6854 & 4.7 \\
\hline & & $2 \mathrm{H} 4$ & Fab & 6855 & 4.6 \\
\hline
\end{tabular}

${ }^{a}$ The possible neutralization mechanisms for flavivirus antibodies discussed in the text are summarized below. 14c10: blocking receptor binding (Teoh et al. 2012), 1F4: blocking virus attachment (Fibriansah et al. 2014), 1A1D-2: blocking virus attachment by binding to hidden epitopes (Lok et al. 2008), 2D22: blocking capsid reorganization required for virus fusion (Fibriansah et al. 2015a), 2H2: inhibition of virus maturation (Wang et al. 2013), E53: binding to partially immature heterogeneous virions (Cherrier et al. 2009), 1H10: enhancing immature virus attachment to endosomal membrane (Wirawan et al. 2019), 5J7: blocking receptor binding and capsid stabilization (Fibriansah et al. 2015b), E16: blocking capsid reorganization required for virus fusion (Kaufmann et al. 2006), ZIKV-117: capsid stabilization (Hasan et al. 2017), ZKA190: inhibition of either cell attachment or membrane fusion (Wang J et al. 2017), C10: capsid stabilization (Zhang et al. 2016).

DI and DI-DII hinges) does not bind to the E proteins near the threefold vertices where the epitope is partially hidden; consequently, only 120 copies of Fab 1F4 interact with a DENV virion (Fibriansah et al. 2014). Additionally, the capacity of Fab to bind onto a virus particle may not be straightforward when the binding sites are not fully occupied, as shown in the density analysis of ZIKV-117 Fab in a cryo-EM reconstruction (Hasan et al. 2017).

\section{Immune Complexes for Icosahedral Viruses at Intermediate States}

Antibodies have been used to capture intermediate states in the assembly pathway of enteroviruses. There are two major enterovirus particles in infected host cells: empty procapsids (noninfectious) and mature virions (infectious). Upon binding to cellular receptors, the native virions are converted into uncoated intermediates called A(altered)particles (Shingler et al. 2013). Binding to the E18 antibody transforms infectious EV-A71 into A-particles and triggers genome release (Plevka et al. 2014). Uniquely, CV-A6 A-particles are biochemically and structurally stable, which enabled the A-particle-Fab complex to be reconstructed at a $3.8-\AA$ resolution (Xu et al. 2017). 2G8 shows cross-reactivity against the CV-A10 procapsid, the mature virion, and the A-particle, suggesting that the epitopes on $2 \mathrm{G} 8$ are structurally conserved among the three capsid forms (Zhu R et al. 2018).

The dynamic conformational changes occurring during the flavivirus life cycle have also been investigated by cryoEM. Differing from the mature virus particles with smooth 
Table 3 Summary of cryo-EM structures from glycoprotein-antibody complexes.

\begin{tabular}{|c|c|c|c|c|c|c|}
\hline Genus & Virus name & Antigen & Antibody & Fragment & EMD codes & Resolution ( \\
\hline \multirow[t]{48}{*}{ Lentivirus } & \multirow{48}{*}{$\begin{array}{l}\text { Human } \\
\text { immunodeficiency } \\
\text { virus (HIV) }\end{array}$} & \multirow{11}{*}{$\begin{array}{l}\text { HIV-1 BaL } \\
\text { virion }\end{array}$} & A12 & VHH & (Tomo) 5544/5551 & \\
\hline & & & $\mathrm{m} 36$ & $\mathrm{~V}_{\mathrm{H}}$ & (Tomo) 5552/5553/5554/5555 & \\
\hline & & & $17 \mathrm{~b}$ & $\operatorname{IgG}$ & (Tomo) 5456 & 22 \\
\hline & & & VRC01 & $\operatorname{IgG}$ & (Tomo) 5457 & 24 \\
\hline & & & VRC03 & $\operatorname{IgG}$ & (Tomo) 5458 & 23 \\
\hline & & & VRC02 & $\mathrm{Fab}$ & (Tomo) 5459 & 23 \\
\hline & & & VRC02 & $\operatorname{IgG}$ & (Tomo) 5460 & 25 \\
\hline & & & VRC01/17b & $\operatorname{IgG}$ & (Tomo) 5461 & 28 \\
\hline & & & b12 & $\mathrm{Fab}$ & (Tomo) 5018/5021 & $20 / 20$ \\
\hline & & & $17 \mathrm{~b}$ & $\mathrm{Fab}$ & (Tomo) 5020/5023 & $20 / 20$ \\
\hline & & & 17b/A32 & $\mathrm{Fab}$ & 0466 & 13.08 \\
\hline & & \multirow{13}{*}{$\begin{array}{l}\text { BG505 } \\
\text { SOSIP.664 }\end{array}$} & 17b/8ANC195 & $\mathrm{Fab}$ & 7516/(Tomo) 3096 & $3.54 / 23$ \\
\hline & & & $3 \mathrm{BNC} 117$ & $\mathrm{Fab}$ & 8644 & 4.4 \\
\hline & & & 3BNC117/PGT145 & $\mathrm{Fab}$ & 8643 & 4.3 \\
\hline & & & 3BC 315 & $\mathrm{Fab}$ & 3067 & 9.3 \\
\hline & & & BG1/8ANC195 & $\mathrm{Fab}$ & 8693 & 6.2 \\
\hline & & & PG9/8ANC195 & $\mathrm{Fab}$ & 8695 & 11.5 \\
\hline & & & 3417 & $\mathrm{Fab}$ & $7552 / 7553 / 7554 / 7555 / 7556 / 7557$ & $\begin{array}{l}4.7 / 4.7 / 4.7 / 4.7 / \\
\quad 4.7 / 4.7\end{array}$ \\
\hline & & & VRC34.01 & $\mathrm{Fab}$ & 8125 & 17 \\
\hline & & & BF520.1 & $\mathrm{Fab}$ & 9166 & 4.8 \\
\hline & & & PGT128 & $\mathrm{Fab}$ & $3121 / 3120$ & $4.36 / 4.47$ \\
\hline & & & $17 \mathrm{~b}$ & $\mathrm{Fab}$ & 8730 & 8.6 \\
\hline & & & PGV04 & $\mathrm{Fab}$ & $5779 / 5780 / 5781$ & $5.8 / 7.9 / 8.2$ \\
\hline & & & PGT151 & $\mathrm{Fab}$ & 9062 & 4.5 \\
\hline & & \multirow[t]{5}{*}{$\begin{array}{l}\text { BG505 DS- } \\
\text { SOSIP.664 }\end{array}$} & $\begin{array}{l}\text { vFP/VRC03/ } \\
\text { PGT122 }\end{array}$ & $\mathrm{Fab}$ & $7622 / 7621 / 7459 / 7460$ & $4 / 4 / 3.8 / 3.6$ \\
\hline & & & vFP & $\mathrm{Fab}$ & $8420 / 8421 / 8422$ & $8.58 / 14.7 / 19.6$ \\
\hline & & & PGT145 & $\mathrm{Fab}$ & 8427 & 6.8 \\
\hline & & & 2G12/VRC03 & $\mathrm{Fab}$ & 8981 & 8.8 \\
\hline & & & $\begin{array}{l}\text { PGT122/VRC03/ } \\
\text { FP antibodies }\end{array}$ & $\mathrm{Fab}$ & $\begin{array}{l}\text { 9189/20189/20191/9359/9320/ } \\
\text { 9319/8977 }\end{array}$ & $\begin{array}{l}3.8 / 4.3 / 3.5 / 3.7 / \\
4.2 / 4 / 3.18\end{array}$ \\
\hline & & $\begin{array}{l}\text { 462c } \\
\quad \text { SOSIP.664 }\end{array}$ & $\mathrm{VRC} 01_{\mathrm{GL}}$ & $\mathrm{Fab}$ & 9294/9295/9303/9304 & $3.8 / 3.8 / 4.8 / 4.8$ \\
\hline & & \multirow[t]{5}{*}{ B41 SOSIP. 664} & $17 \mathrm{~b}$ & $\mathrm{Fab}$ & 8713 & 3.7 \\
\hline & & & PGV04 & $\mathrm{Fab}$ & 8716 & 7.4 \\
\hline & & & b12 & $\mathrm{Fab}$ & 8717 & 3.6 \\
\hline & & & 21c/8ANC195 & $\mathrm{Fab}$ & 9038 & 4.06 \\
\hline & & & PGT151 & $\mathrm{Fab}$ & 9030 & 6.7 \\
\hline & & $\begin{array}{l}\text { ZM197 SOSIP. } \\
\quad 664\end{array}$ & VRC01 & $\mathrm{Fab}$ & 3059 & 9.32 \\
\hline & & \multirow{2}{*}{$\begin{array}{l}\text { PC64M18C043 } \\
\text { FL Env }\end{array}$} & PGT151 & $\mathrm{Fab}$ & 7858 & 3.1 \\
\hline & & & $\begin{array}{l}\text { PGT151/PCT64- } \\
\text { 35S }\end{array}$ & $\mathrm{Fab}$ & 7859 & 6.8 \\
\hline & & $\begin{array}{l}\text { PC64M18C043 } \\
\text { SOSIP. } 664\end{array}$ & PGT151 & $\mathrm{Fab}$ & 7860 & 4.9 \\
\hline & & \multirow{3}{*}{$\begin{array}{l}\text { PC64M4C054 } \\
\text { SOSIP. } 664\end{array}$} & PCT64-13C & $\mathrm{Fab}$ & 7863/7864/7089 & $5.1 / 30 / 13.2$ \\
\hline & & & РCT64-13F & $\mathrm{Fab}$ & 7862 & 30 \\
\hline & & & PCT64-35S & $\mathrm{Fab}$ & $7865 / 7866$ & $5.5 / 8.2$ \\
\hline & & $\begin{array}{l}\text { PC64M4C054 } \\
\text { FL Env }\end{array}$ & $\begin{array}{l}\text { PGT151/PCT64- } \\
\text { 13C }\end{array}$ & $\mathrm{Fab}$ & 7861 & 30 \\
\hline & & \multirow[t]{2}{*}{ JR-FL Env $\Delta \mathrm{CT}$} & PGT151 & $\mathrm{Fab}$ & $3308 / 3309$ & $4.19 / 4.3$ \\
\hline & & & PGT151/10E8 & $\mathrm{Fab}$ & 3312 & 8.8 \\
\hline & & $\begin{array}{l}\text { AMC011 } \\
\text { SOSIP.v4.2 }\end{array}$ & PGV04 & $\mathrm{Fab}$ & 8302 & 6.2 \\
\hline & & \multirow{2}{*}{$\begin{array}{l}\text { KNH1144 } \\
\text { SOSIP. gp140 }\end{array}$} & VRC03 & $\mathrm{Fab}$ & 2484 & 6 \\
\hline & & & $17 \mathrm{~b}$ & $\mathrm{Fab}$ & (Tomo) 5462 & 8.8 \\
\hline
\end{tabular}


Table 3 (continued)

\begin{tabular}{|c|c|c|c|c|c|c|}
\hline Genus & Virus name & Antigen & Antibody & Fragment & EMD codes & Resolution ( \\
\hline Lymphocryptovirus & Epstein-Barr virus (EBV) & glycoprotein & AMMO1 & $\mathrm{Fab}$ & $7344 / 7345$ & $4.8 / 10$ \\
\hline \multirow[t]{3}{*}{ Betacoronavirus } & \multirow[t]{2}{*}{$\begin{array}{l}\text { Middle East respiratory syndrome- } \\
\text { related coronavirus (MERS-CoV) }\end{array}$} & \multirow[t]{2}{*}{$\mathrm{S}$ protein } & G4 & $\mathrm{Fab}$ & $\begin{array}{l}8783 / 8784 / 8785 / 8786 / 8787 / \\
8788 / 8789 / 8790 / 8791 / 8792 / \\
8793\end{array}$ & $\begin{array}{l}4 / 3.6 / 4.8 / 4.6 / 4.8 / \\
\quad 4.7 / 5 / 4.5 / 4 / 4 / \\
11.5\end{array}$ \\
\hline & & & LCA60 & $\mathrm{Fab}$ & 0401/0402 & $3.5 / 3.6$ \\
\hline & $\begin{array}{l}\text { Severe acute respiratory syndrome } \\
\text { coronavirus (SARS-CoV) }\end{array}$ & $\mathrm{S}$ protein & S230 & $\mathrm{Fab}$ & $0403 / 0404$ & $4.2 / 4.5$ \\
\hline \multirow[t]{6}{*}{ Alphainfluenzavirus } & \multirow[t]{6}{*}{ Influenza virus } & \multirow[t]{4}{*}{ Influenza virion } & $6 \mathrm{~F} 12$ & $\mathrm{IgG}$ & (Tomo) 6610/6611 & \multirow[t]{2}{*}{$25 / 25$} \\
\hline & & & $\mathrm{C} 179$ & $\mathrm{IgG}$ & (Tomo) 5684/5685 & \\
\hline & & & $7 \mathrm{~B} 2$ & $\operatorname{IgG}$ & (Tomo) 6612 & 25 \\
\hline & & & $3 \mathrm{~F} 5$ & $\operatorname{IgG}$ & (Tomo) 6613/6614 & $25 / 25$ \\
\hline & & \multirow[t]{2}{*}{ HA protein } & K1915 & $\mathrm{scFv}$ & $8561 / 8562 / 8563 / 8564$ & $4.8 / 4.8 / 4.8 / 4.8$ \\
\hline & & & H7.5 & $\mathrm{Fab}$ & $9142 / 9143 / 9145$ & $7.4 / 9.2 / 7.4$ \\
\hline \multirow[t]{8}{*}{ Ebolavirus } & \multirow[t]{8}{*}{ Ebola virus (EBOV) } & \multirow[t]{5}{*}{ glycoprotein } & $100 / 114$ & $\mathrm{Fab}$ & $3310 / 3311$ & $7.2 / 6.7$ \\
\hline & & & c2G4/c13C6 & $\mathrm{IgG} / \mathrm{Fab}$ & 8240 & 4.3 \\
\hline & & & c13C6/BDBV91 & $\mathrm{IgG} / \mathrm{Fab}$ & 8241 & 5.5 \\
\hline & & & $\mathrm{c} 4 \mathrm{G} 7 / \mathrm{c} 13 \mathrm{C} 6$ & $\mathrm{IgG} / \mathrm{Fab}$ & 8242 & 4.3 \\
\hline & & & ADI-15878 & $\mathrm{Fab}$ & $8935 / 8936$ & $4.14 / 4.29$ \\
\hline & & \multirow[t]{3}{*}{ VLPs } & c13C6 & $\operatorname{IgG}$ & (Tomo) 8226 & 25 \\
\hline & & & $\mathrm{c} 2 \mathrm{G} 4$ & $\mathrm{IgG}$ & (Tomo) 8227 & 25 \\
\hline & & & $\mathrm{c} 4 \mathrm{G} 7$ & $\mathrm{IgG}$ & (Tomo) 8228 & 25 \\
\hline
\end{tabular}

surfaces, immature virions appear as rough particles with 60 spikes comprising three $\mathrm{E}$ and three prM molecules (the pr peptide on top of each trimeric spike) (Perera and Kuhn 2008). As the pr peptide is cleaved during virus maturation and is absent in mature virions, anti-prM Fabs (e.g. $2 \mathrm{H} 2$ and 1H10) form complexes with immature DENV (Fig. 2K, 2N) (Wang et al. 2013; Wirawan et al. 2019). Highly crossreactive E53, a fusion-loop-specific antibody, binds preferentially to spikes on immature DENV and WNV particles (Cherrier et al. 2009). Because these antibodies can trap flaviviruses in immature states, the neutralizing mechanism for them may depend on their capacity to block the normal transition occurring during the maturation process.

Many cryo-EM studies have been performed to investigate antibody-virus particle interactions for different functional states, including the following ones: (1) Intermediate complexes during 'breathing' motion. Although each cryo-EM reconstruction usually represents a static snapshot of a specific conformation, structural plasticity in immune complexes can also be visualized. Fab 1A1D-2 induces large conformation changes in the $\mathrm{E}$ protein and binds to normally partially hidden epitopes (Lok et al. 2008). Cryo-EM studies have also revealed that Fab 1A1D-2 only binds to epitopes near the fivefold and threefold vertices, suggesting that the extent of the breathing might be not evenly distributed over the viral surface. (2) Size variations in the viral shells at different temperatures. It was found that when exposed to $37^{\circ} \mathrm{C}$, DENV virions expand in size when compared with the structure at $4{ }^{\circ} \mathrm{C}$ (Fibriansah et al. 2013). The unexpanded virions at $4{ }^{\circ} \mathrm{C}$ are covered by 180 copies of the 2D22 Fab (Fig. 2I, 2L), whereas only 120 Fab copies are present on some expanded virions at $37{ }^{\circ} \mathrm{C}$ (Fig. 2J, 2M), as based on 2D and 3D classification of extracted virus-antibody particles (Fibriansah et al. 2015a). (3) Fusion intermediates. A low $\mathrm{pH}$-triggered rearrangement of the E protein is required for virus-cell membrane fusion during entry of flaviviruses into the cell. The E16 Fab trapped WNV in a prefusion state when the virions were exposed to low $\mathrm{pH}$ (Kaufmann et al. 2009). C10, a bNAb for DENV, can structurally lock the E protein of ZIKV at acidic conditions (Rouvinski et al. 2015; Zhang et al. 2016).

\section{Enveloped Viruses Without Icosahedral Symmetry}

Many severe human diseases are caused by structurally polymorphic enveloped viruses (e.g., HIV-1, influenza and Ebola viruses). Glycoprotein-specific antibody-inducing epitopes on the viral surface have been studied directly using cryo-ET. The open conformations of the HIV-1 Env spike induced by Fab b12 or CD4/Fab 17b have been characterized using cryo-ET analysis (Liu et al. 2008). The extent to which the C179 antibody bound to the stem domain of hemagglutinin (HA) on the influenza virus was also investigated by cryo-ET, revealing that most of the HA trimers on virions were accessible to this antibody (Harris et al. 2013).

High-resolution SPA of glycoprotein-antibody complexes requires stabilized protein samples, a good example 
A

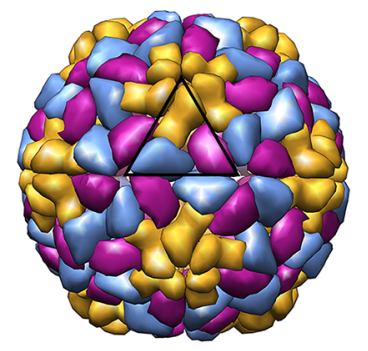

E

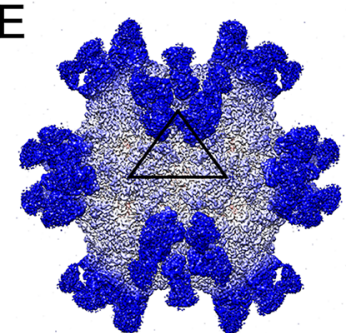

I

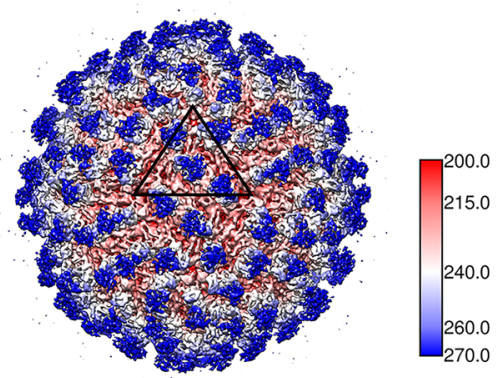

$\mathrm{L}$

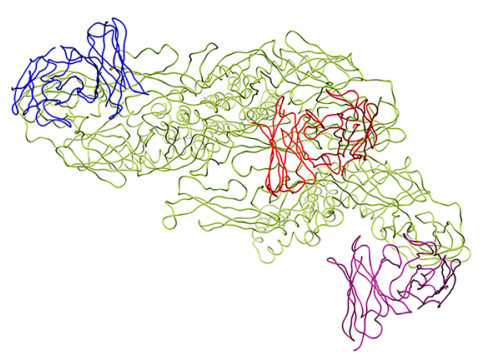

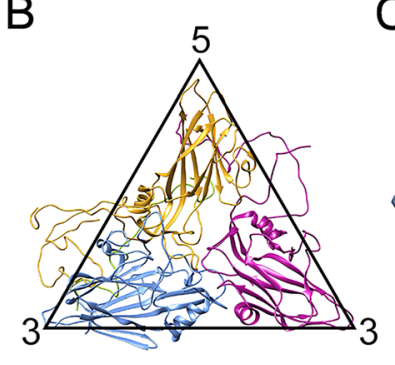

C

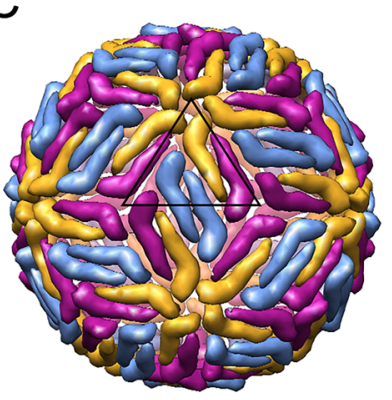

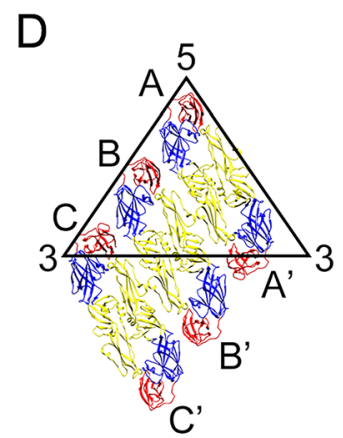

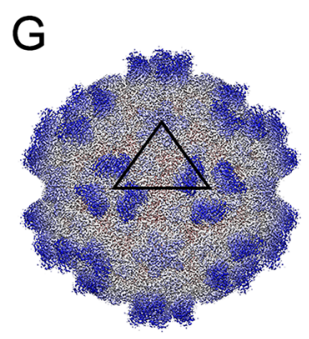

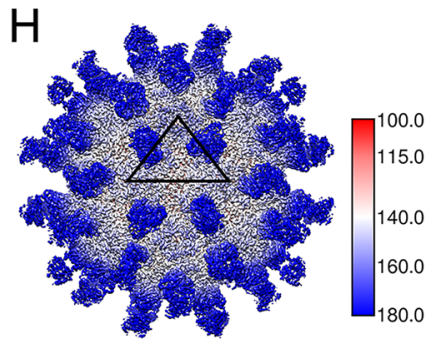

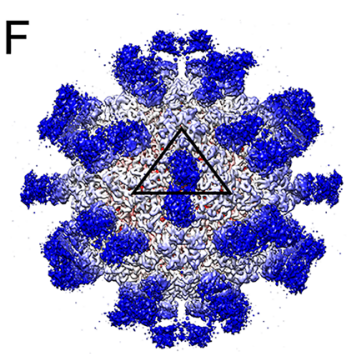

$J$

K
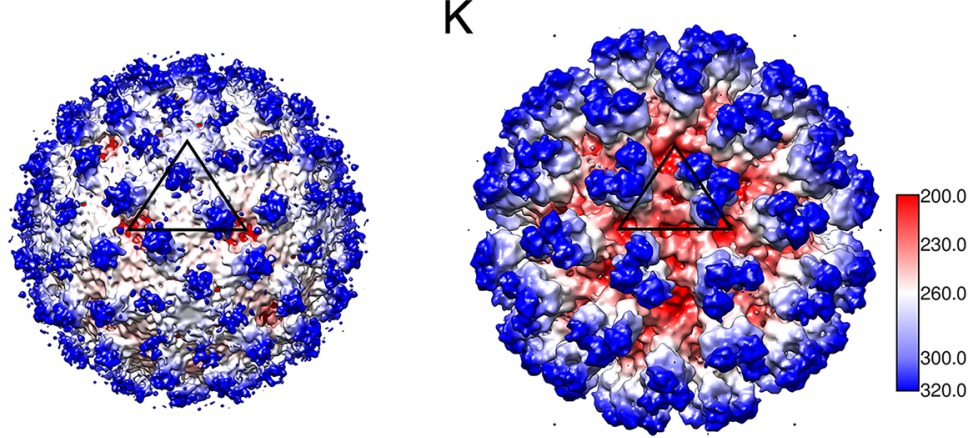

M

N

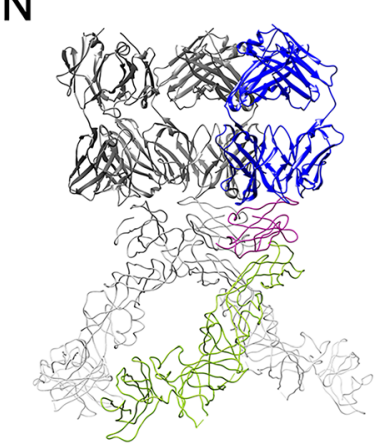

Fig. 2 Virus-antibody complexes from picornaviruses ( $\mathrm{T}=$ pseudo 3 ) and flaviviruses $(\mathrm{T}=3)$. A The capsid shell on human rhinovirus 14 (PDB-4RHV) is formed by 60 copies of VP1 (gold), VP2 (blue), and VP3 (magenta). B In an ASU, VP1, VP2 and VP3 are folded with a similar "jelly-roll" topology. C The dengue virus capsid structure (PDB-1K4R) is shown as a smooth herringbone lattice of 90 dimers ('E dimers'). The three E molecules in an ASU are colored gold, blue and magenta. D E dimers in two ASUs. The E protein's ectodomain has three domains: DI (red), DII (yellow) and DIII (blue). E-H CryoEM structures of Fab-picornaviruses complexes, where 60 copies of Fab (blue) bind to the outermost surface of the virus (white) near the 5-, 2-, 3- and q3-fold vertices (5-fold: EMD-6757, 2-fold: EMD-6366, 3-fold: EMD-8762 and q3-fold: EMD-9604, respectively. See Table 1 for related information). An icosahedral ASU is outlined in each map. I, L 180 copies of Fab 2D22 (blue) bind to DENV2 at $4{ }^{\circ} \mathrm{C}$ (EMD2967). J, M 120 copies of Fab $2 \mathrm{D} 22$ (blue) bind to DENV2 at $37{ }^{\circ} \mathrm{C}$ (EMD-2968). K, $\mathbf{N} 180$ copies of Fab $2 \mathrm{H} 2$ bind to immature DENV2 (EMD-5674). There are 60 characteristic spikes on the immature virion. Each spike is a hetero-hexamer consisting of three prM (magenta) and three E molecules (green). Virions are radially colored as in the side bar with the number corresponding to the radius (in $\AA$ ). Note that the picornavirus and flavivirus particles are not drawn to scale. The external diameters of picornaviruses and flaviviruses are $\sim 30 \mathrm{~nm}$ and $\sim 50 \mathrm{~nm}$, respectively. 
of which is the engineered HIV-1 Env trimer with SOSIP mutations (Sanders et al. 2002). Mature HIV-1 possesses trimers of gp41/gp120 homodimers as the surface spikes. Although some spike epitopes are present on the gp120 monomer, it would be desirable to choose native-like trimers for structural analysis because they are the major target of the neutralizing antibodies elicited by natural infection (Sanders and Moore 2017; Ward and Wilson 2017). SOSIP mutants contain an introduced disulfide (SOS) bond between the gp120 and gp41 ectodomains, and an introduced isoleucine to proline mutation in gp41 to promote trimer formation. Engineered glycoprotein trimers from other enveloped viruses (e.g., Middle East respiratory syndrome coronavirus, MERS-CoV, and parainfluenza virus types 1-4) were designed to present the antigenically optimal prefusion conformation (Pallesen et al. 2017; Stewart-Jones et al. 2018). Glycoproteins from Ebola virus were modified by removing the mucin-like domain, assembled as soluble trimers, and then studied in a complex with the ADI-15878 Fab by SPA (Murin et al. 2018). Except for the above-mentioned trimeric forms, glycoprotein complexes containing more than one viral glycoprotein (e.g., gH/gL/gp42 from Epstein-Barr virus) have also been used for cryo-EM antibody-antigen studies (Snijder et al. 2018).

Cryo-EM structures of glycoprotein-antibody complexes are usually captured in intermediate states. Twenty antibody classes targeting six epitopes on the prefusion closed HIV-1 Env trimer have been characterized using SPA (Table 3) and crystallographic studies (Chuang et al. 2019). 'Breathing' by HIV-1 B41 SOSIP.664 trimers was found to expose the b12 epitope (Ozorowski et al. 2017), and a similar motion by influenza HA protomers was also revealed by SPA (Turner et al. 2019). S230 binding induces fusogenic conformational rearrangements in the SARS-CoV S glycoprotein, while the MERS-CoV S glycoprotein remains its prefusion conformation upon LCA60 binding (Yuan et al. 2017; Walls et al. 2019).

\section{Virus-Like Particles (VLPs) as Antigen Presentation Platforms}

VLPs with features that are structurally and immunologically indistinguishable from live viruses are used as alternative models for cryo-EM studies, especially when the viruses need to be manipulated in high-level biosafety facilities. Chikungunya virus (CHIKV) is a mosquitotransmitted human pathogen with $\mathrm{T}=4$ icosahedral symmetry. On its surface, three E2 molecules form the major component of the viral spike and serve as the main target for antibodies. Because handling live infectious CHIKV requires biosafety level 3 facilities, cryo-EM studies are performed with the safe CHIKV vaccine strain (CHIKV 181/25) (Fox et al. 2015) or CHIK VLPs (Akahata et al. 2010; Sun et al. 2013; Jin et al. 2015). The CHK-265 Fab cross-links two E2 molecules from neighboring spikes (Fox et al. 2015), while the footprints of C9 and IM-CKV063 Fabs on VLPs span the neighboring E2 subunits within one viral spike (Jin et al. 2015). CHK-152 may cross-link the flexible domain B to the domain A within an E2 molecule, and thus inhibiting the exposure of the fusion loop on domain II of E1 (Sun et al. 2013).

VLPs have also served as controllable scaffolds for loading antigenic cargos (Charlton Hume and Lua 2017). Currently, the most commonly used VLPs are rigid icosahedral or helical particles, and flexible platforms are beginning to be promising roles for antigen loading $(\mathrm{Hu}-$ dalla et al. 2014; Rao et al. 2018). To protect against different human papillomavirus (HPV, pseudo $\mathrm{T}=7$ icosahedral) infections, chimeric VLPs containing the epitopes from three HPV types have been generated and studied by cryo-EM (Li et al. 2018). Recently, computationally designed nanoparticles have also been examined by cryo-EM as a new platform for presenting the respiratory syncytial virus F glycoprotein trimer (Marcandalli et al. 2019). Being able to add antigenic protein modules to tailorable platforms is a tantalizing way of studying highly virulent viruses like Crimean-Congo hemorrhagic fever, Nipah, and Ebola viruses. It is also likely that the cryo-EM characterization of VLPs and nanoparticles will accelerate the development of new vaccine platforms.

\section{Conclusions}

Cryo-EM has evolved in recent years into a powerful technique for elucidating the structural basis of virusantibody interactions. Compared with traditional X-ray crystallography, cryo-EM offers the following advantages: (1) it can investigate conformational epitopes with sequentially discontinuous residues on icosahedral virions; (2) it avoids tedious screening for diffractable crystals and can be incorporated into a standardized process for rapid and rational vaccine development; (3) it can help with analyzing intrinsic heterogeneous samples, like highly glycosylated viral glycoproteins; and (4) it can be exploited for developing and characterizing high-quality vaccine platforms. Finally, cryo-EM studies of antigen-antibody complexes are beginning to clarify the mechanisms of epitope-paratope recognition at atomic resolution, so we expect that high-resolution cryo-EM structures will play more important roles in future at guiding vaccine development.

Acknowledgements This work was funded by the National Natural Science Foundation of China (Grant Nos. 31570161 and 31770169), 
and the "One-Three-Five" Strategic Programs of the Wuhan Institute of Virology, Chinese Academy of Sciences (Grant No. Y605211SA3). We are thankful to the Center for Instrumental Analysis and Metrology of Wuhan Institute of Virology, CAS, for providing cryo-EM support. We also thank Dr. Sandra Cheesman for editing the English text of a draft of this manuscript.

\section{Compliance with Ethical Standards}

Conflict of interest The authors declare that they have no conflict of interest.

Animal and Human Rights Statement This article does not contain any studies with human or animal subjects performed by any of the authors.

Open Access This article is distributed under the terms of the Creative Commons Attribution 4.0 International License (http://creative commons.org/licenses/by/4.0/), which permits unrestricted use, distribution, and reproduction in any medium, provided you give appropriate credit to the original author(s) and the source, provide a link to the Creative Commons license, and indicate if changes were made.

\section{References}

Akahata W, Yang ZY, Andersen H, Sun S, Holdaway HA, Kong WP, Lewis MG, Higgs S, Rossmann MG, Rao S, Nabel GJ (2010) A virus-like particle vaccine for epidemic Chikungunya virus protects nonhuman primates against infection. Nat Med 16:334-338

Almeida JD, Waterson AP (1969) The morphology of virus-antibody interaction. Adv Virus Res 15:307-338

Anasir MI, Poh CL (2019) Structural vaccinology for viral vaccine design. Front Microbiol 10:738

Cao L, Liu P, Yang P, Gao Q, Li H, Sun Y, Zhu L, Lin J, Su D, Rao Z, Wang X (2019) Structural basis for neutralization of hepatitis A virus informs a rational design of highly potent inhibitors. PLoS Biol 17:e3000229

Charlton Hume HK, Lua LHL (2017) Platform technologies for modern vaccine manufacturing. Vaccine 35:4480-4485

Cherrier MV, Kaufmann B, Nybakken GE, Lok SM, Warren JT, Chen BR, Nelson CA, Kostyuchenko VA, Holdaway HA, Chipman PR, Kuhn RJ, Diamond MS, Rossmann MG, Fremont DH (2009) Structural basis for the preferential recognition of immature flaviviruses by a fusion-loop antibody. EMBO J 28:3269-3276

Chuang GY, Zhou J, Acharya P, Rawi R, Shen CH, Sheng Z, Zhang B, Zhou T, Bailer RT, Dandey VP, Doria-Rose NA, Louder MK, McKee K, Mascola JR, Shapiro L, Kwong PD (2019) Structural survey of broadly neutralizing antibodies targeting the HIV-1 Env trimer delineates epitope categories and characteristics of recognition. Structure 27(196-206):e196

Crowe JE Jr (2017) Principles of broad and potent antiviral human antibodies: insights for vaccine design. Cell Host Microbe 22:193-206

Dai L, Wang Q, Qi J, Shi Y, Yan J, Gao GF (2016) Molecular basis of antibody-mediated neutralization and protection against flavivirus. IUBMB Life 68:783-791

Danev R, Yanagisawa H, Kikkawa M (2019) Cryo-Electron microscopy methodology: current aspects and future directions. Trends Biochem Sci. https://doi.org/10.1016/j.tibs.2019.04.008

Dejnirattisai W, Wongwiwat W, Supasa S, Zhang X, Dai X, Rouvinski A, Jumnainsong A, Edwards C, Quyen NTH, Duangchinda T, Grimes JM, Tsai WY, Lai CY, Wang WK,
Malasit P, Farrar J, Simmons CP, Zhou ZH, Rey FA, Mongkolsapaya J, Screaton GR (2015) A new class of highly potent, broadly neutralizing antibodies isolated from viremic patients infected with dengue virus. Nat Immunol 16:170-177

Domanska A, Flatt JW, Jukonen JJJ, Geraets JA, Butcher SJ (2019) A 2.8-angstrom-resolution cryo-electron microscopy structure of human parechovirus 3 in complex with fab from a neutralizing antibody. J Virol 93:e01597-18

Dong Y, Liu Y, Jiang W, Smith TJ, Xu Z, Rossmann MG (2017) Antibody-induced uncoating of human rhinovirus B14. Proc Natl Acad Sci USA 114:8017-8022

Earl LA, Subramaniam S (2016) Cryo-EM of viruses and vaccine design. Proc Natl Acad Sci USA 113:8903-8905

Ekiert DC, Kashyap AK, Steel J, Rubrum A, Bhabha G, Khayat R, Lee JH, Dillon MA, O'Neil RE, Faynboym AM, Horowitz M, Horowitz L, Ward AB, Palese P, Webby R, Lerner RA, Bhatt RR, Wilson IA (2012) Cross-neutralization of influenza A viruses mediated by a single antibody loop. Nature 489:526-532

Fibriansah G, Ng TS, Kostyuchenko VA, Lee J, Lee S, Wang JQ, Lok SM (2013) Structural changes in dengue virus when exposed to a temperature of $37^{\circ} \mathrm{C}$. J Virol 87:7585-7592

Fibriansah G, Tan JL, Smith SA, de Alwis AR, Ng TS, Kostyuchenko VA, Ibarra KD, Wang J, Harris E, de Silva A, Crowe JE Jr, Lok SM (2014) A potent anti-dengue human antibody preferentially recognizes the conformation of $\mathrm{E}$ protein monomers assembled on the virus surface. EMBO Mol Med 6:358-371

Fibriansah G, Ibarra KD, Ng TS, Smith SA, Tan JL, Lim XN, Ooi JSG, Kostyuchenko VA, Wang JQ, de Silva AM, Harris E, Crowe JE, Lok SM (2015a) Cryo-EM structure of an antibody that neutralizes dengue virus type 2 by locking E protein dimers. Science 349:88-91

Fibriansah G, Tan JL, Smith SA, de Alwis R, Ng TS, Kostyuchenko VA, Jadi RS, Kukkaro P, de Silva AM, Crowe JE, Lok SM (2015b) A highly potent human antibody neutralizes dengue virus serotype 3 by binding across three surface proteins. Nat Commun 6:6341

Finlay WJ, Bloom L, Grant J, Franklin E, Shuilleabhain DN, Cunningham O (2017) Phage display: a powerful technology for the generation of high-specificity affinity reagents from alternative immune sources. Methods Mol Biol 1485:85-99

Flyak AI, Ilinykh PA, Murin CD, Garron T, Shen X, Fusco ML, Hashiguchi T, Bornholdt ZA, Slaughter JC, Sapparapu G, Klages C, Ksiazek TG, Ward AB, Saphire EO, Bukreyev A, Crowe JE Jr (2015) Mechanism of human antibody-mediated neutralization of Marburg virus. Cell 160:893-903

Flyak AI, Shen X, Murin CD, Turner HL, David JA, Fusco ML, Lampley R, Kose N, Ilinykh PA, Kuzmina N, Branchizio A, King H, Brown L, Bryan C, Davidson E, Doranz BJ, Slaughter JC, Sapparapu G, Klages C, Ksiazek TG, Saphire EO, Ward AB, Bukreyev A, Crowe JE Jr (2016) Cross-reactive and potent neutralizing antibody responses in human survivors of natural ebolavirus infection. Cell 164:392-405

Fox JM, Long F, Edeling MA, Lin H, van Duijl-Richter MKS, Fong RH, Kahle KM, Smit JM, Jin J, Simmons G, Doranz BJ, Crowe JE Jr, Fremont DH, Rossmann MG, Diamond MS (2015) Broadly neutralizing alphavirus antibodies bind an epitope on E2 and inhibit entry and egress. Cell 163:1095-1107

Harris AK, Meyerson JR, Matsuoka Y, Kuybeda O, Moran A, Bliss D, Das SR, Yewdell JW, Sapiro G, Subbarao K, Subramaniam S (2013) Structure and accessibility of HA trimers on intact 2009 H1N1 pandemic influenza virus to stem region-specific neutralizing antibodies. Proc Natl Acad Sci USA 110:4592-4597

Harrison SC, Olson AJ, Schutt CE, Winkler FK, Bricogne G (1978) Tomato bushy stunt virus at 2.9-A resolution. Nature 276:368-373

Hasan SS, Miller A, Sapparapu G, Fernandez E, Klose T, Long F, Fokine A, Porta JC, Jiang W, Diamond MS, Crowe JE Jr, Kuhn 
RJ, Rossmann MG (2017) A human antibody against Zika virus crosslinks the $\mathrm{E}$ protein to prevent infection. Nat Commun 8:14722

Hogle JM, Chow M, Filman DJ (1985) Three-dimensional structure of poliovirus at 2.9 A resolution. Science 229:1358-1365

Holbrook MR (2017) Historical perspectives on flavivirus research. Viruses 9:E97

Hoogenboom HR (2005) Selecting and screening recombinant antibody libraries. Nat Biotechnol 23:1105-1116

Hudalla GA, Sun T, Gasiorowski JZ, Han HF, Tian YF, Chong AS, Collier JH (2014) Gradated assembly of multiple proteins into supramolecular nanomaterials. Nat Mater 13:829-836

Ilca SL, Kotecha A, Sun X, Poranen MM, Stuart DI, Huiskonen JT (2015) Localized reconstruction of subunits from electron cryomicroscopy images of macromolecular complexes. Nat Commun 6:8843

Jiang W, Tang L (2017) Atomic cryo-EM structures of viruses. Curr Opin Struct Biol 46:122-129

Jin J, Liss NM, Chen DH, Liao M, Fox JM, Shimak RM, Fong RH, Chafets D, Bakkour S, Keating S, Fomin ME, Muench MO, Sherman MB, Doranz BJ, Diamond MS, Simmons G (2015) Neutralizing monoclonal antibodies block chikungunya virus entry and release by targeting an epitope critical to viral pathogenesis. Cell Rep 13:2553-2564

Kaufmann B, Nybakken GE, Chipman PR, Zhang W, Diamond MS, Fremont DH, Kuhn RJ, Rossmann MG (2006) West Nile virus in complex with the Fab fragment of a neutralizing monoclonal antibody. Proc Natl Acad Sci USA 103:12400-12404

Kaufmann B, Chipman PR, Holdaway HA, Johnson S, Fremont DH, Kuhn RJ, Diamond MS, Rossmann MG (2009) Capturing a flavivirus pre-fusion intermediate. PLoS Pathog 5:e1000672

Kimmis BD, Downing C, Tyring S (2018) Hand-foot-and-mouth disease caused by coxsackievirus A6 on the rise. Cutis 102:353-356

Kohler G, Milstein C (1975) Continuous cultures of fused cells secreting antibody of predefined specificity. Nature 256:495-497

Lee H, Cifuente JO, Ashley RE, Conway JF, Makhov AM, Tano Y, Shimizu H, Nishimura Y, Hafenstein S (2013) A strain-specific epitope of enterovirus 71 identified by cryo-electron microscopy of the complex with fab from neutralizing antibody. J Virol 87:11363-11370

Li Z, Song S, He M, Wang D, Shi J, Liu X, Li Y, Chi X, Wei S, Yang Y, Wang Z, Li J, Qian H, Yu H, Zheng Q, Yan X, Zhao Q, Zhang J, Gu Y, Li S, Xia N (2018) Rational design of a tripletype human papillomavirus vaccine by compromising viral-type specificity. Nat Commun 9:5360

Liu J, Bartesaghi A, Borgnia MJ, Sapiro G, Subramaniam S (2008) Molecular architecture of native HIV-1 gp120 trimers. Nature 455:109-U176

Liu Y, Pan J, Jenni S, Raymond DD, Caradonna T, Do KT, Schmidt AG, Harrison SC, Grigorieff N (2017) CryoEM structure of an influenza virus receptor-binding site antibody-antigen interface. J Mol Biol 429:1829-1839

Lok SM, Kostyuchenko V, Nybakken GE, Holdaway HA, Battisti AJ, Sukupolvi-Petty S, Sedlak D, Fremont DH, Chipman PR, Roehrig JT, Diamond MS, Kuhn RJ, Rossmann MG (2008) Binding of a neutralizing antibody to dengue virus alters the arrangement of surface glycoproteins. Nat Struct Mol Biol 15:312-317

Marcandalli J, Fiala B, Ols S, Perotti M, de van der Schueren W, Snijder J, Hodge E, Benhaim M, Ravichandran R, Carter L, Sheffler W, Brunner L, Lawrenz M, Dubois P, Lanzavecchia A, Sallusto F, Lee KK, Veesler D, Correnti CE, Stewart LJ, Baker D, Lore K, Perez L, King NP (2019) Induction of potent neutralizing antibody responses by a designed protein nanoparticle vaccine for respiratory syncytial virus. Cell 176:1420-1431 e1417
Meyerson JR, Tran EE, Kuybeda O, Chen W, Dimitrov DS, Gorlani A, Verrips T, Lifson JD, Subramaniam S (2013) Molecular structures of trimeric HIV-1 Env in complex with small antibody derivatives. Proc Natl Acad Sci USA 110:513-518

Murin CD, Bruhn JF, Bornholdt ZA, Copps J, Stanfield R, Ward AB (2018) Structural basis of pan-ebolavirus neutralization by an antibody targeting the glycoprotein fusion loop. Cell Rep 24(2723-2732):e2724

Ozorowski G, Pallesen J, de Val N, Lyumkis D, Cottrell CA, Torres JL, Copps J, Stanfield RL, Cupo A, Pugach P, Moore JP, Wilson IA, Ward AB (2017) Open and closed structures reveal allostery and pliability in the HIV-1 envelope spike. Nature 547:360-363

Pallesen J, Wang N, Corbett KS, Wrapp D, Kirchdoerfer RN, Turner HL, Cottrell CA, Becker MM, Wang L, Shi W, Kong WP, Andres EL, Kettenbach AN, Denison MR, Chappell JD, Graham BS, Ward AB, McLellan JS (2017) Immunogenicity and structures of a rationally designed prefusion MERS-CoV spike antigen. Proc Natl Acad Sci USA 114:E7348-E7357

Parent KN, Schrad JR, Cingolani G (2018) Breaking symmetry in viral icosahedral capsids as seen through the lenses of X-ray crystallography and cryo-electron microscopy. Viruses-Basel 10:E67

Perera R, Kuhn RJ (2008) Structural proteomics of dengue virus. Curr Opin Microbiol 11:369-377

Plevka P, Lim PY, Perera R, Cardosa J, Suksatu A, Kuhn RJ, Rossmann MG (2014) Neutralizing antibodies can initiate genome release from human enterovirus 71. Proc Natl Acad Sci USA 111:2134-2139

Rao G, Fu Y, Li N, Yin J, Zhang J, Wang M, Hu Z, Cao S (2018) Controllable assembly of flexible protein nanotubes for loading multifunctional modules. ACS Appl Mater Interfaces 10:25135-25145

Ren J, Wang X, Hu Z, Gao Q, Sun Y, Li X, Porta C, Walter TS, Gilbert RJ, Zhao Y, Axford D, Williams M, McAuley K, Rowlands DJ, Yin W, Wang J, Stuart DI, Rao Z, Fry EE (2013) Picornavirus uncoating intermediate captured in atomic detail. Nat Commun 4:1929

Rodenhuis-Zybert IA, Wilschut J, Smit JM (2011) Partial maturation: an immune-evasion strategy of dengue virus? Trends Microbiol 19:248-254

Rossmann MG, Arnold E, Erickson JW, Frankenberger EA, Griffith JP, Hecht HJ, Johnson JE, Kamer G, Luo M, Mosser AG et al (1985) Structure of a human common cold virus and functional relationship to other picornaviruses. Nature 317:145-153

Rouvinski A, Guardado-Calvo P, Barba-Spaeth G, Duquerroy S, Vaney MC, Kikuti CM, Navarro Sanchez ME, Dejnirattisai W, Wongwiwat W, Haouz A, Girard-Blanc C, Petres S, Shepard WE, Despres P, Arenzana-Seisdedos F, Dussart P, Mongkolsapaya J, Screaton GR, Rey FA (2015) Recognition determinants of broadly neutralizing human antibodies against dengue viruses. Nature 520:109-113

Sanders RW, Moore JP (2017) Native-like Env trimers as a platform for HIV-1 vaccine design. Immunol Rev 275:161-182

Sanders RW, Vesanen M, Schuelke N, Master A, Schiffner L, Kalyanaraman R, Paluch M, Berkhout B, Maddon PJ, Olson WC, Lu M, Moore JP (2002) Stabilization of the soluble, cleaved, trimeric form of the envelope glycoprotein complex of human immunodeficiency virus type 1. J Virol 76:8875-8889

Shen PS (2018) The 2017 Nobel Prize in chemistry: cryo-EM comes of age. Anal Bioanal Chem 410:2053-2057

Shingler KL, Yoder JL, Carnegie MS, Ashley RE, Makhov AM, Conway JF, Hafenstein S (2013) The enterovirus 71 A-particle forms a gateway to allow genome release: a cryoEM study of picornavirus uncoating. PLoS Pathog 9:e1003240

Shingler KL, Cifuente JO, Ashley RE, Makhov AM, Conway JF, Hafenstein S (2015) The enterovirus 71 procapsid binds 
neutralizing antibodies and rescues virus infection in vitro. J Virol 89:1900-1908

Snijder J, Ortego MS, Weidle C, Stuart AB, Gray MD, McElrath MJ, Pancera M, Veesler D, McGuire AT (2018) An antibody targeting the fusion machinery neutralizes dual-tropic infection and defines a site of vulnerability on Epstein-Barr virus. Immunity 48(799-811):e799

Stephenson KE, Barouch DH (2016) Broadly neutralizing antibodies for HIV eradication. Curr HIV/AIDS Rep 13:31-37

Stewart-Jones GBE, Chuang GY, Xu K, Zhou T, Acharya P, Tsybovsky Y, Ou L, Zhang B, Fernandez-Rodriguez B, Gilardi V, Silacci-Fregni C, Beltramello M, Baxa U, Druz A, Kong WP, Thomas PV, Yang Y, Foulds KE, Todd JP, Wei H, Salazar AM, Scorpio DG, Carragher B, Potter CS, Corti D, Mascola JR, Lanzavecchia A, Kwong PD (2018) Structure-based design of a quadrivalent fusion glycoprotein vaccine for human parainfluenza virus types 1-4. Proc Natl Acad Sci USA 115:12265-12270

Sun SY, Xiang Y, Akahata W, Holdaway H, Pal P, Zhang XZ, Diamond MS, Nabel GJ, Rossmann MG (2013) Structural analyses at pseudo atomic resolution of Chikungunya virus and antibodies show mechanisms of neutralization. Elife 2:e00435

Teoh EP, Kukkaro P, Teo EW, Lim AP, Tan TT, Yip A, Schul W, Aung M, Kostyuchenko VA, Leo YS, Chan SH, Smith KG, Chan AH, Zou G, Ooi EE, Kemeny DM, Tan GK, Ng JK, Ng ML, Alonso S, Fisher D, Shi PY, Hanson BJ, Lok SM, MacAry PA (2012) The structural basis for serotype-specific neutralization of dengue virus by a human antibody. Sci Transl Med 4:139ra183

Tran EE, Borgnia MJ, Kuybeda O, Schauder DM, Bartesaghi A, Frank GA, Sapiro G, Milne JL, Subramaniam S (2012) Structural mechanism of trimeric HIV-1 envelope glycoprotein activation. PLoS Pathog 8:e1002797

Tran EE, Nelson EA, Bonagiri P, Simmons JA, Shoemaker CJ, Schmaljohn CS, Kobinger GP, Zeitlin L, Subramaniam S, White JM (2016a) Mapping of ebolavirus neutralization by monoclonal antibodies in the zmapp cocktail using cryo-electron tomography and studies of cellular entry. J Virol 90:7618-7627

Tran EE, Podolsky KA, Bartesaghi A, Kuybeda O, Grandinetti G, Wohlbold TJ, Tan GS, Nachbagauer R, Palese P, Krammer F, Subramaniam S (2016b) Cryo-electron microscopy structures of chimeric hemagglutinin displayed on a universal influenza vaccine candidate. MBio 7:e00257

Turner HL, Pallesen J, Lang S, Bangaru S, Urata S, Li S, Cottrell CA, Bowman CA, Crowe JE Jr, Wilson IA, Ward AB (2019) Potent anti-influenza $\mathrm{H} 7$ human monoclonal antibody induces separation of hemagglutinin receptor-binding head domains. PLoS Biol 17:e3000139

Walls AC, Xiong X, Park YJ, Tortorici MA, Snijder J, Quispe J, Cameroni E, Gopal R, Dai M, Lanzavecchia A, Zambon M, Rey FA, Corti D, Veesler D (2019) Unexpected receptor functional mimicry elucidates activation of coronavirus fusion. Cell 176(1026-1039):e1015

Wang X, Peng W, Ren J, Hu Z, Xu J, Lou Z, Li X, Yin W, Shen X, Porta C, Walter TS, Evans G, Axford D, Owen R, Rowlands DJ, Wang J, Stuart DI, Fry EE, Rao Z (2012) A sensor-adaptor mechanism for enterovirus uncoating from structures of EV71. Nat Struct Mol Biol 19:424-429

Wang Z, Li L, Pennington JG, Sheng J, Yap ML, Plevka P, Meng G, Sun L, Jiang W, Rossmann MG (2013) Obstruction of dengue virus maturation by Fab fragments of the $2 \mathrm{H} 2$ antibody. J Virol 87:8909-8915

Wang J, Bardelli M, Espinosa DA, Pedotti M, Ng TS, Bianchi S, Simonelli L, Lim EXY, Foglierini M, Zatta F, Jaconi S, Beltramello M, Cameroni E, Fibriansah G, Shi J, Barca T, Pagani I, Rubio A, Broccoli V, Vicenzi E, Graham V, Pullan S, Dowall S, Hewson R, Jurt S, Zerbe O, Stettler K, Lanzavecchia
A, Sallusto F, Cavalli A, Harris E, Lok SM, Varani L, Corti D (2017) A human Bi-specific antibody against zika virus with high therapeutic potential. Cell 171(229-241):e215

Wang X, Zhu L, Dang M, Hu Z, Gao Q, Yuan S, Sun Y, Zhang B, Ren J, Kotecha A, Walter TS, Wang J, Fry EE, Stuart DI, Rao Z (2017) Potent neutralization of hepatitis A virus reveals a receptor mimic mechanism and the receptor recognition site. Proc Natl Acad Sci USA 114:770-775

Ward AB, Wilson IA (2017) The HIV-1 envelope glycoprotein structure: nailing down a moving target. Immunol Rev 275:21-32

Wirawan M, Fibriansah G, Marzinek JK, Lim XX, Ng TS, Sim AYL, Zhang Q, Kostyuchenko VA, Shi J, Smith SA, Verma CS, Anand G, Crowe JE Jr, Bond PJ, Lok SM (2019) Mechanism of enhanced immature dengue virus attachment to endosomal membrane induced by prM antibody. Structure 27(253-267):e258

Xu L, Zheng Q, Li S, He M, Wu Y, Li Y, Zhu R, Yu H, Hong Q, Jiang J, Li Z, Li S, Zhao H, Yang L, Hou W, Wang W, Ye X, Zhang J, Baker TS, Cheng T, Zhou ZH, Yan X, Xia N (2017) Atomic structures of Coxsackievirus A6 and its complex with a neutralizing antibody. Nat Commun 8:505

Yang C, Gong R, de Val N (2019) Development of neutralizing antibodies against zika virus based on its envelope protein structure. Virol Sin 34:168-174

Ye X, Fan C, Ku Z, Zuo T, Kong L, Zhang C, Shi J, Liu Q, Chen T, Zhang Y, Jiang W, Zhang L, Huang Z, Cong Y (2016) Structural basis for recognition of human enterovirus 71 by a bivalent broadly neutralizing monoclonal antibody. PLoS Pathog 12:e1005454

Yu H, Cowling BJ (2019) Remaining challenges for prevention and control of hand, foot, and mouth disease. Lancet Child Adolesc Health 3:373-374

Yuan Y, Cao D, Zhang Y, Ma J, Qi J, Wang Q, Lu G, Wu Y, Yan J, Shi Y, Zhang X, Gao GF (2017) Cryo-EM structures of MERS$\mathrm{CoV}$ and SARS-CoV spike glycoproteins reveal the dynamic receptor binding domains. Nat Commun 8:15092

Zhang X, Jin L, Fang Q, Hui WH, Zhou ZH (2010) 3.3 A cryo-EM structure of a nonenveloped virus reveals a priming mechanism for cell entry. Cell 141:472-482

Zhang S, Kostyuchenko VA, Ng TS, Lim XN, Ooi JSG, Lambert S, Tan TY, Widman DG, Shi J, Baric RS, Lok SM (2016) Neutralization mechanism of a highly potent antibody against Zika virus. Nat Commun 7:13679

Zheng Q, Zhu R, Xu L, He M, Yan X, Liu D, Yin Z, Wu Y, Li Y, Yang L, Hou W, Li S, Li Z, Chen Z, Li Z, Yu H, Gu Y, Zhang J, Baker TS, Zhou ZH, Graham BS, Cheng T, Li S, Xia N (2019) Atomic structures of enterovirus D68 in complex with two monoclonal antibodies define distinct mechanisms of viral neutralization. Nat Microbiol 4:124-133

Zhu D, Wang X, Fang Q, Van Etten JL, Rossmann MG, Rao Z, Zhang X (2018) Pushing the resolution limit by correcting the Ewald sphere effect in single-particle Cryo-EM reconstructions. Nat Commun 9:1552

Zhu L, Sun Y, Fan J, Zhu B, Cao L, Gao Q, Zhang Y, Liu H, Rao Z, Wang X (2018a) Structures of Coxsackievirus A10 unveil the molecular mechanisms of receptor binding and viral uncoating. Nat Commun 9:4985

Zhu L, Xu K, Wang N, Cao L, Wu J, Gao Q, Fry EE, Stuart DI, Rao Z, Wang J, Wang X (2018b) Neutralization mechanisms of two highly potent antibodies against human enterovirus 71 . MBio 9:e01013-18

Zhu R, Xu L, Zheng Q, Cui Y, Li S, He M, Yin Z, Liu D, Li S, Li Z, Chen Z, Yu H, Que Y, Liu C, Kong Z, Zhang J, Baker TS, Yan X, Hong Zhou Z, Cheng T, Xia N (2018) Discovery and structural characterization of a therapeutic antibody against coxsackievirus A10. Sci Adv 4:eaat7459 